\title{
Mutations in HHEX are not a common cause of monogenic forms of beta cell dysfunction
}

\author{
J. A. L. Minton • M. van de Bunt • C. Boustred • \\ K. Hussain • A. T. Hattersley • S. Ellard • A. L. Gloyn
}

Received: 27 February 2007 / Accepted: 5 June 2007 / Published online: 6 July 2007

(C) Springer-Verlag 2007

Keywords Diabetes · Genetics · HEX · HHEX · MODY . Monogenic diabetes · Permanent neonatal diabetes . Persistent hyperinsulinaemic hypoglycaemia of infancy . PHHI · PNDM

J. A. L. Minton and M. van de Bunt contributed equally to this study.

Electronic supplementary material Supplementary material is available in the online version of this article at doi 10.1007/s00125007-0748-3 and is accessible for authorised users.

\footnotetext{
J. A. L. Minton $\cdot$ C. Boustred · A. T. Hattersley $\cdot$ S. Ellard Institute of Biomedical and Clinical Science, Peninsula Medical School,

Exeter, UK

J. A. L. Minton

e-mail: jayne.minton@pms.ac.uk

C. Boustred

e-mail: c.r.boustred@exeter.ac.uk

A. T. Hattersley

e-mail: a.t.hattersley@exeter.ac.uk

S. Ellard

e-mail: s.ellard@exeter.ac.uk

M. van de Bunt $\cdot$ A. L. Gloyn $(\bowtie)$

Diabetes Research Laboratories, Oxford Centre for Diabetes, Endocrinology and Metabolism, University of Oxford, Churchill Hospital,

Old Road, Headington,

Oxford OX3 7LJ, UK

e-mail: anna.gloyn@drl.ox.ac.uk

M. van de Bunt

e-mail: martijn.vandebunt@ocdem.ox.ac.uk

K. Hussain

Institute of Child Health, Great Ormond Street Hospital,

London, UK

e-mail: K.Hussain@ich.ucl.ac.uk
}

\author{
Abbreviations \\ HEX haematopoietically expressed homeobox protein \\ HI hypoglycaemia of infancy \\ HNF $1 \alpha$ hepatocyte nuclear factor $1 \alpha$ \\ PDX1 pancreatic and duodenal homeobox protein 1 \\ PNDM permanent neonatal diabetes
}

To the Editor: Haematopoietically expressed homeobox protein (HEX), a divergent homeobox transcription factor, is encoded by the HHEX gene and is required for organogenesis of the ventral pancreas [1]. Mouse embryos lacking HHEX show a complete failure of ventral pancreatic specification [1] and have deletions of the forebrain, midbrain and rostral hindbrain [2]. HEX functions from very early in embryogenesis (E4.5) through adulthood and is involved in the regulation of genes at multiple developmental states, including mature tissue and cell type [3]. HHEX is expressed before the gene encoding the key pancreatic transcription factor, pancreatic and duodenal homeobox protein $1(P D X 1)$, and mouse embryos lacking HHEX do not express $P D X 1$ in the ventral pancreas, whereas expression in the dorsal pancreas is unaffected [1]. HEX has also been shown to activate hepatocyte nuclear factor $1 \alpha(\mathrm{HNF} 1 \alpha)$, an important transcription factor not only in beta cell development but also in the regulation of insulin secretion [4].

Mutations in key transcription factors for pancreatic development are responsible for monogenic forms of beta cell dysfunction, resulting in both hyper- and hypoglycaemia [5, 6]. Homozygous or compound heterozygous mutations in PDX1 cause permanent neonatal diabetes (PNDM) with pancreatic agenesis [5], whilst heterozygous mutations result in MODY [5]. Mutations in the genes 
encoding HNF1 $\alpha$ ( $H N F 1 A$, also known as $T C F 1), H N F 1 \beta$ (HNF1B, also known as TCF2) and HNF4 $\alpha$ (HNF4A) also cause MODY [5]. It has recently been shown that mutations in HNF4A can also cause transient hypoglycaemia [6]. A number of cases of PNDM have extra-pancreatic features, including cerebellar agenesis [7] and other neurological abnormalities [5], supporting a role in disease pathogenesis for additional genes essential to both pancreatic and brain development.

There is considerable overlap between the genetic aetiology of monogenic forms of beta cell dysfunction and the more common polygenic type 2 diabetes. It is well established that rare mutations in key genes involved in pancreatic beta cell development and function result in monogenic or early-onset diabetes, whilst common genetic variation in the same genes predisposes individuals to adult-onset type 2 diabetes [8]. A genome-wide scan for association, performed in subjects with type 2 diabetes, revealed that $H H E X$ is an excellent candidate susceptibility gene for type 2 diabetes [9]. A linkage disequilibrium block on chromosome 10q23 containing the insulin-degrading enzyme (IDE), kinesin family member 11 (KIF11) and HHEX genes has been shown to be associated with type 2 diabetes [9]. Given the essential role of HHEX in the development of the pancreas, its possible role in susceptibility to type 2 diabetes, and our knowledge of the overlap in the genetic aetiologies of type 2 diabetes and monogenic forms of pancreatic beta cell dysfunction, we hypothesised that mutations in HHEX may play a role in the pathogenesis of PNDM, MODY and hypoglycaemia of infancy (HI).

To evaluate the putative contribution of HHEX in monogenic forms of beta cell dysfunction we screened all four exons (including the intron-exon junctions) the $5^{\prime}$ and $3^{\prime}$ untranslated regions and the promoter of HHEX in unrelated subjects with unexplained PNDM $(n=30)$, MODY $(n=32)$ or HI $(n=45)$. The clinical characteristics of the patients screened are shown in Table 1. HHEX is located on chromosome 10q23.33 and encodes a 270 amino acid protein. The exon structure of HHEX was established using the GenBank sequence NM_002729.3 (for GenBank database see http://www.ncbi.nlm.nih.gov/Genbank/, last accessed in June 2007). M13-tailed primers were designed to amplify HHEX in five fragments (primer sequences are presented in Supplementary Table 1). Amplicons were sequenced on an ABI3700 DNA analyser using standard protocols. Sequence variants were confirmed by re-amplifying a fresh dilution of DNA. No mutations were identified that explained PNDM, MODY or HI. A total of eight rare SNPs were identified (Table 2). In one subject with $\mathrm{HI}$ a novel variant (c. 431C >G, p. F129L) was detected. The mutated residue is conserved across species and is located close to the homeobox region (K137-L196). To establish the frequency of this variant in normal controls, exons 2 and 3 were sequenced in samples from 96 blood donors of European descent from a panel of commercially available DNA. The F129L variant was not present in the 192 normal chromosomes tested. DNA was available from the affected mother and unaffected father. The F129L variant was present in the father but not the affected mother. Gender assignment of parental DNA was confirmed by an in-house sex-determining region Y (SRY) PCR assay (details available on request) to exclude the possibility of sample mix up. Therefore, since co-segregation with $\mathrm{HI}$ could not be demonstrated, it is not the cause of beta cell dysfunction in these individuals and therefore unlikely to be pathogenic. Seven other rare, silent or intronic variants were identified: c. $-137 \mathrm{G}>\mathrm{A}$; c. $-46 \mathrm{C}>\mathrm{A}$; c. $-11 \mathrm{G}>\mathrm{A} ;$ c. $-5 \mathrm{C}>\mathrm{G}$; c.318G $>$ A, p.T106T; c.541-29T $>$ G, c. $592-22 \mathrm{C}>$ T. According to the dbSNP build 126 database (see http://www.ncbi.nlm.nih. gov/projects/SNP/, last accessed in June 2007) an rs number has been assigned to one of the eight variants identified (rs2275729, c.541-29T $>$ G). The presence and frequency of these variants was determined in 96 blood donors of European descent. Both the c. $-5 \mathrm{C}>\mathrm{G}$ and c. $-137 \mathrm{G}>\mathrm{A}$ variants were not present in the control population. Parental DNA was available
Table 1 Clinical characteristics of subjects studied

Data presented as means $\pm \mathrm{SD}$

$N A$ data not available, $O H A$

oral hypoglycaemic agent

${ }^{\text {a }}$ Age at diagnosis in weeks

${ }^{\mathrm{b}}$ Age at diagnosis in years

\begin{tabular}{|c|c|c|c|}
\hline Variable & PNDM & MODY & $\mathrm{HI}$ \\
\hline$n$ & 30 & 32 & 45 \\
\hline Sex $(\%$ male $)$ & 70 & 31 & 49 \\
\hline Age at diagnosis & $7.4 \pm 8.2^{\mathrm{a}}$ & $17.1 \pm 6.4^{\mathrm{b}}$ & $9.9 \pm 0.06^{\mathrm{a}}$ \\
\hline Age at examination (years) & NA & $27.8 \pm 13.6$ & $5.11 \pm 6.08$ \\
\hline Fasting glucose $(\mathrm{mmol} / \mathrm{l})$ & NA & NA & $1.91 \pm 0.56$ \\
\hline BMI $\left(\mathrm{kg} / \mathrm{m}^{2}\right)$ & NA & $24.7 \pm 13.6$ & NA \\
\hline \multicolumn{4}{|l|}{ Current treatment $(\%)$} \\
\hline Insulin/OHA/diet/none/not known & $100 / 0 / 0 / 0 / 0$ & $50 / 15 / 28 / 0 / 6$ & \\
\hline $\begin{array}{l}\text { Diazoxide/pancreatectomy/octreotide/diet/ } \\
\text { none/not known }\end{array}$ & & & $49 / 31 / 5 / 2 / 2 / 11$ \\
\hline Birth weight $(\mathrm{g})$ & $2,256 \pm 853$ & NA & $3,436 \pm 879$ \\
\hline Under tenth percentile (\%) & 42 & - & - \\
\hline Over 70th percentile (\%) & - & - & 58 \\
\hline
\end{tabular}


Table 2 HHEX gene variants detected in patients with PNDM $(n=30)$, MODY $(n=32)$ or HI $(n=45)$

\begin{tabular}{|c|c|c|c|c|c|}
\hline \multirow{2}{*}{$\frac{\mathrm{SNP}}{\text { c. }-137 \mathrm{G}>\mathrm{A}}$} & \multirow{2}{*}{$\begin{array}{l}\text { Exon } \\
\text { Promoter }\end{array}$} & \multicolumn{3}{|c|}{ Minor allele frequency (MAF) } & \multirow{2}{*}{$\begin{array}{l}\text { rs number } \\
\text { NA }\end{array}$} \\
\hline & & PNDM & $0 / 60$ & 0.00 & \\
\hline & & MODY & $1 / 64$ & 0.01 & \\
\hline & & $\mathrm{HI}$ & $0 / 90$ & 0.00 & \\
\hline & & Controls & $0 / 192$ & 0.00 & \\
\hline \multirow[t]{4}{*}{ c. $-46 \mathrm{C}>\mathrm{A}$} & Promoter & PNDM & $2 / 60$ & 0.03 & NA \\
\hline & & MODY & $1 / 64$ & 0.01 & \\
\hline & & $\mathrm{HI}$ & $1 / 90$ & 0.01 & \\
\hline & & Controls & $6 / 192$ & 0.03 & \\
\hline \multirow[t]{4}{*}{ c. $-11 \mathrm{G}>\mathrm{A}$} & Exon 1 & PNDM & $3 / 60$ & 0.05 & NA \\
\hline & & MODY & $1 / 64$ & 0.01 & \\
\hline & & $\mathrm{HI}$ & $8 / 90$ & 0.09 & \\
\hline & & Controls & $6 / 192$ & 0.03 & \\
\hline \multirow[t]{4}{*}{ c. $-5 \mathrm{C}>\mathrm{G}$} & Exon 1 & PNDM & $1 / 60$ & 0.01 & NA \\
\hline & & MODY & $0 / 64$ & 0.00 & \\
\hline & & $\mathrm{HI}$ & $0 / 90$ & 0.00 & \\
\hline & & Controls & $0 / 192$ & 0.00 & \\
\hline \multirow[t]{4}{*}{ c.318G $>$ A, p.T106T } & Exon 1 & PNDM & $1 / 60$ & 0.01 & NA \\
\hline & & MODY & $1 / 64$ & 0.01 & \\
\hline & & $\mathrm{HI}$ & $0 / 90$ & 0.00 & \\
\hline & & Controls & $6 / 192$ & 0.03 & \\
\hline \multirow[t]{4}{*}{ c. $431 \mathrm{C}>\mathrm{G}, \mathrm{p} . \mathrm{F} 129 \mathrm{~L}$} & Exon 2 & PNDM & $0 / 60$ & 0.00 & NA \\
\hline & & MODY & $0 / 64$ & 0.00 & \\
\hline & & $\mathrm{HI}$ & $1 / 90$ & 0.01 & \\
\hline & & Controls & $0 / 192$ & 0.00 & \\
\hline \multirow[t]{4}{*}{ c. $541-29 \mathrm{~T}>\mathrm{G}$} & Intron 2 & PNDM & $7 / 60$ & 0.12 & rs 2275729 \\
\hline & & MODY & $10 / 64$ & 0.16 & \\
\hline & & $\mathrm{HI}$ & $8 / 90$ & 0.09 & \\
\hline & & Controls & $17 / 192$ & 0.09 & \\
\hline \multirow{4}{*}{ c. $592-22 \mathrm{C}>\mathrm{T}$} & Intron 3 & PNDM & $0 / 60$ & 0.00 & NA \\
\hline & & MODY & $1 / 64$ & 0.01 & \\
\hline & & HI & $0 / 90$ & 0.00 & \\
\hline & & Controls & $1 / 192$ & $<0.01$ & \\
\hline
\end{tabular}

$N A$ not available

for the proband with the c. $-5 \mathrm{C}>\mathrm{T}$ variant and sequencing demonstrated that the variant was present in the unaffected father. Unfortunately, parental DNA was not available for the proband with the c.137G $>$ A variant, and we are therefore unable to exclude a role for this variant in the aetiology of MODY.

Linkage to chromosome 10q23 has not been reported in the UK MODYX families previously included in a genome-wide scan for linkage [10]. Family samples and data are not available for the PNDM and HI samples, and so linkage to chromosome 10q23 cannot be excluded. It is therefore possible that some of our cases are linked to this region, which would suggest a role of known and unknown regulatory regions of $H H E X$ in the pathogenesis of beta cell dysfunction.

In conclusion, despite the convincing emerging evidence for a role of common genetic variation at the HHEX locus in susceptibility to type 2 diabetes, our data suggest that it is unlikely that mutations in HHEX are a common cause of unexplained MODY, PNDM or HI.
Acknowledgements The authors thank S. Flanagan for her assistance with compiling the clinical data on the patients with hypoglycaemia of infancy. This work was supported in Exeter by the European Union (Integrated Project EURODIALSHM-CT-2006518153 in the Framework Program 6 [FP6] of the European Community). This work was supported in Oxford by Diabetes UK. A. L. Gloyn is a Diabetes UK RD Lawrence Research Fellow; A. T. Hattersley is a Wellcome Trust Research Leave Fellow. M. van de Bunt acknowledges the support of the Dutch Diabetes Research Foundation.

Duality of interest The authors declare that there is no duality of interest associated with this manuscript.

\section{References}

1. Bort R, Martinez-Barbera JP, Beddington RS, Zaret KS (2004) Hex homeobox gene-dependent tissue positioning is required for organogenesis of the ventral pancreas. Development 131:797-806 
2. Martinez Barbera JP, Clements M, Thomas P et al (2000) The homeobox gene Hex is required in definitive endodermal tissues for normal forebrain, liver and thyroid formation. Development 127:2433-2445

3. Bogue CW, Ganea GR, Sturm E, Ianucci R, Jacobs HC (2000) Hex expression suggests a role in the development and function of organs derived from foregut endoderm. Dev Dyn 219: 84-89

4. Tanaka H, Yamamoto T, Ban T et al (2005) Hex stimulates the hepatocyte nuclear factor $1 \alpha$-mediated activation of transcription. Arch Biochem Biophys 442:117-124

5. Gloyn AL, Ellard S (2006) Defining the genetic aetiology of monogenic diabetes can improve treatment. Expert Opin Pharmacother 7:1759-1767

6. Pearson ER, Boj SF, Steele AM et al (2007) Macrosomia and hyperinsulinaemic hypoglycaemia in patients with heterozygous mutations in the $H N F 4 A$ gene. PLos Medicine 4:e118

7. Sellick GS, Barker KT, Stolte-Dijkstra I et al (2004) Mutations in PTF1A cause pancreatic and cerebellar agenesis. Nat Genet 36:1301-1305

8. McCarthy MI (2004) Progress in defining the molecular basis of type 2 diabetes mellitus through susceptibility-gene identification. Hum Mol Genet 13:R33-R41

9. Sladek R, Rocheleau G, Rung J et al (2007) A genome-wide association study identifies novel risk loci for type 2 diabetes. Nature 445:881-885

10. Frayling TM, Lindgren CM, Chevre JC et al (2003) A genomewide scan in families with maturity-onset diabetes of the young: evidence for further genetic heterogeneity. Diabetes $52: 872-881$ 